\title{
Modernity, Intertextuality and Decolonization: Some Examples from Estonian and Latvian Literature ${ }^{1}$
}

\author{
ANNELI MIHKELEV
}

\begin{abstract}
Colonization influences the colonized country politically, economically and culturally, and colonial traces persist everywhere in a colonized society, particularly in social manners, behaviour and culture. After a period of colonization, a period of decolonization is needed. According to W. D. Mignolo, decolonization is the long-term processes involving the bureaucratic, cultural, linguistic, and psychological divesting of colonial power. The result of decolonization is a new people and community. The processes involved depend on cultural transfer, cultural relations and modernisation of smaller and peripheral national cultures. All of these processes make it possible for small and peripheral nations to find their own originality within European culture. An "external" or "alien" culture may function as a metatext in an "own" culture and it can describe the "own" culture itself via auto-communication. The literary works of smaller national cultures, such as Estonia and Latvia, represent cultural processes in the process of modernisation and the modernist period in literature at the beginning of the $20^{\text {th }}$ century and also in the $21^{\text {st }}$ century. The paper analyses different texts from "alien" cultures (Shakespeare's Hamlet, the Bible etc.) which function as metatexts in "own" culture. Shakespeare's Hamlet as a literary figure has been a very important and influential motif in Estonian literature and culture: Gustav Suits's and Paul-Eerik Rummo's poems used the motif of Hamlet to describe Estonian history and culture. The Bible has influenced Estonian literary culture for a long time. The function of the old biblical myths is to create the eternal, mythical dimension in literary works and create contact with old nations (e.g. Käsu Hans', Juhan Liiv's and Ene Mihkelson's poetry.). Prose writers Rūdolfs Blaumanis' and Eduard Vilde's works represent the Baltic lifestyle, which affected peasants and aristocrats in different ways. Both writers used more of their "own" cultural system and language as metatext to describe the cultural system, rather than using external cultural systems and languages. They transformed realist, romantic and psychological realist styles and languages into internal or "own" cultural systems.
\end{abstract}

1 This work has been supported by the Estonian Research Council within the project IUT18-4 "Estonia between East and West: The Paradigm of the Images of "Own", "Other", "Strange", "Enemy" in Estonian Cultures at the End of the $19^{\text {th }}$ and in the $20^{\text {th }}$ Century”.

DOI: http://dx.doi.org/10.12697/IL.2015.20.1.12 
All of these stories and poems demonstrate how smaller and peripheral cultures find their own original national cultures and how cultural influences and transformations work through cultural dynamics. Small nations can communicate with other cultures, and they can communicate with us; we can describe our "own" culture via auto-communication.

Keywords: colonisation, decolonization, modernity, intertextuality, Estonian literature, Latvian literature

Estonia and Latvia have been colonized several times in different periods of history. Every colonization influences the colonized country politically, economically and culturally, and colonial traces persist everywhere in a colonized society, particularly in social manners, behaviour and culture. After a period of colonization, a period of decolonization is needed. The term "decolonization" existed already in the 1930s but became more popular in the 1960s (Betts 2004: 1). According to Walter D. Mignolo and Linda T. Smith, decolonization includes "long-term processes involving the bureaucratic, cultural, linguistic, and psychological divesting of colonial power" (Mignolo 2011: 52). The result of decolonization is a new people and community (ibid.). Mignolo states that "non-alignment" and "Third World" became almost synonymous terms, and "they made visible the hidden face of modernity, that is, coloniality. Therefore decolonization became a choice by those who needed to delink rather than a decision of those who were in a condition to marginalize" (Mignolo 2011: 52).

Although Mignolo focuses mainly on the colonization of Latin America and the Third World, similar tendencies are also apparent in the Baltic States. Estonia and Latvia were colonized by Germany, Sweden and the Russian Empire. Although Epp Annus has written: “... even though the Soviet Union occupied rather than colonized the Baltic States, the period of occupation nevertheless developed into a period of colonial rule, as the modes of resistance turned into a hybrid coexistence with the new power" (Annus 2012: 37), the Soviet occupation in the $20^{\text {th }}$ century resembled an invasion more than it did colonization. Thomas Salumets's words describe exactly Estonia's and all the Baltic States' complicated colonial encounter:

The occupation of Estonia by the Soviet Union in the $20^{\text {th }}$ century (1940-1941 and 1944-1991) went hand in hand with reverberations of Estonian independence (1918-1939), Baltic German, and past Tsarist colonist practices. In short, colonialism - or more appropriately postcolonialism - in Estonia means a sequence of multiple, at times simultaneous colonizations and their postcolonial aftermaths. (Salumets 2006: 429-430) 
The main question is how it is possible to go through a long decolonization process to reach de-colonial freedom and independent thought, how to come to believe that $20^{\text {th }}$-century modernity is "our modernity", not a copy or imitation of that of the colonizing culture.

The processes involved depend on cultural transfer, cultural relations and modernisation of smaller and peripheral national cultures. All of these processes make it possible for small and peripheral nations to find their own originality within European culture. Yuri Lotman has described these cultural processes as follows:

The dynamics of culture can be represented as neither an isolated immanent process nor the passive sphere of external influences. [...] Intersection with other cultural structures may be achieved in a variety of ways. Thus, an "external" culture in order to enter into our world must cease to be "external" to it. It must find for itself a name and a place in the language of the culture into which it seeks to insert itself. But in order to change from "alien" (chuzhoi) to "own" (svoi) this external culture must, as we can see, submit to a new name in the language of the "internal" culture. (Lotman 2009: 133)

An "external" or "alien" culture may function as a metatext in an "own" culture and it can describe the "own" culture itself via auto-communication. The literary works of smaller national cultures, such as Estonia and Latvia, represent cultural processes in the process of modernisation and the modernist period in literature at the beginning of the $20^{\text {th }}$ century and also in the $21^{\text {st }}$ century.

\section{Hamlet as a metatext}

For example, there is Gustav Suits's poem series Hamleti proloog (The Prologue of Hamlet, 1913), which was published in Suits's second collection Tuulemaa (The Land of Winds, 1913). Hamleti proloog was written to celebrate a very important event in Estonian culture. On 24 August 1913 the Estonia Theatre's new building opened in Tallinn. It was a drama theatre, and later became an opera house. Gustav Suits wrote Hamleti proloog for the opening of the new theatre house. It was a very important day for Estonians. Hamlet, the Danish prince, became a historical symbol as a man who fought during a complicated and hostile time (see Oras 2003: 20-21). Hamleti proloog contains seven poems, and each poem has its own unique structure, but all of the strophes contain three lines, echoing Dante's terza rima from Divina Commedia (1472). Suits used two "external" texts to describe and interpret Estonian culture. But more than the form of terza 
rima connects Suits's prologue with Dante's Divine Comedy; the content of the prologue is similar to Dante's work: the poem series is like a journey through Estonian history and landscapes, and images of reality alternate with images of fantasy or dream motifs. Suits's seven poems form a parallel with purgatory in Dante's work or in religious texts. In the fifth poem, Suits presents the ghost of the great William Shakespeare, who finally has arrived in Estonian theatre and culture, and the protagonist Prince Hamlet is the symbol of that time.

Suits's poem is an Estonian poem, about Estonian culture, but both Dante and Shakespeare help him to talk about Estonian culture; their literary works act as metatexts.

Gustav Suits is not the only poet to use the motif of Hamlet in his works. Paul-Eerik Rummo was one of the major authors of the Estonian poetry innovation of the 1960s. His poem Hamleti laulud (Hamlet's Songs) was published in 1964 in his second collection of poetry, Tule ikka mu rõommude juurde (Always Come to My Joys). The Estonian researcher Lauri Sommer has stated that Rummo's "early writing was lyrical", and that the "universal quality of his thoughts stem from their gently tragic, self-ironic and playful framing" (Sommer 2001: 131).

Another Estonian researcher Marja Unt has written:

Rummo's earlier poetry, mostly what appeared in Anchor Heaver [Ankruhiivaja, 1962, A. M.], has a brighter world view and more optimistic manner. The title suggests the main motif - setting off on a journey, filled with hope and looking towards the wide expanse ahead. This kind of mood perfectly suited the changed situation in the early 1960s, when the Soviet regime was somewhat mellowing and all kinds of restrictions were relaxed. Hope and perception of the wider world carried on to the next collection, Always Come to My Joys, although the youthful zeal seems to have retreated here and more serious tones have crept in, together with a sense of danger and realisation of life's fragility, which is especially typical of the short cycle Hamleti laulud (The Songs of Hamlet) (Unt 2006: 6).

It is obvious that more serious aspects, together with a sense of danger and realization of life's fragility, are represented in Rummo's second collection, especially in the poem Hamleti laulud (see also Olesk 2001: 444).

The second part of the song sounds like an answer to Shakespeare's protagonist Hamlet: "Yes, to be, to be, certainly to be" (Rummo 2006: 9, trans. by Jüri Talvet and H. L. Hix). The existential question of Hamlet gets a certain and vital answer, and that answer brings a new meaning in the context of existential paradigm which had a strong influence in Estonian culture in the 1960s (see Veidemann 2000: 50; Mihkelev 2013). 
MIHKELEV

This poem was innovative in Estonian literature and was used in choral music at the beginning of the 1960s. It formed a prologue to the innovations in Estonian theatre in the second half of the 1960s. Paul-Eerik Rummo's play Tuhkatriinumäng (Cinderella Game, 1969), which alludes to Prince Hamlet, is one of the significant plays in the development of Estonian drama (see Kruuspere 2006). Luule Epner has pointed out the key-words of the change in Estonian drama in the 1960s: play, myths, especially literary myths, and ritual. The most important mythical and symbolic figures were Antigone and Hamlet, with Hamlet the more significant (Epner 1988: 170-176).

Consequently, Hamlet as a literary figure has been a very important and influential motif in Estonian literature and culture, and Rummo's text forms the axis around which revolve not only written texts but also such cultural aspects as theatre performances and music.

\section{The Bible as a metatext}

The Bible is a text which has influenced Estonian culture, especially Estonian literary culture, for a long time: there are lots of quotations, allusions and symbols from the Bible in Estonian literary texts. The function of the old biblical myths is to create the eternal, mythical dimension in literary works and create contact with old nations. There are several Estonian texts in which the destiny of Jews is identified with the destiny of Estonians, e.g. Oh, ma vaene Tarto liin! (Oh, I Am the Poor Town of Tartu) by Käsu Hans, 1708. It is the first known poem written by an Estonian, representing Tartu as a town, depicting the story of the conquest and destruction of Tartu during the Nordic War. August Annist points out two thematic and ideological aims of the lament: first, to depict most truly and factually the sad fate of Tartu in 1704-1708, and second to show that everything in this story of suffering was God's punishment meted out on the citizens of Tartu for their sins, and to morally (and patriotically) influence other Livonian towns (Annist 1993: 142; see also Mihkelev 2002: 437-439). The characteristic style of chorales, promoting godliness, refers iconically to the Bible: the whole structure of the text is then completely normal and in accordance with the customary philosophy of the history of the Christian church, where great disasters are seen as God's punishment for all kinds of sins of masses of people, and as an edifying lesson for the rest of the world (ibid.) Annist believes that Käsu Hans had been influenced by other stories in the Bible, for instance, by the lamentation of Jeremiah (Annist 1993: 147). According to the new ideology, which became fixed in Käsu Hans's text, Tartu was a town built by humans; it acted against the will of God and was punished so that the others could learn their lessons. 
Another antithesis reveals itself in Käsu Hans's text besides the ideological one - the age-old opposition of town and country. Thus, everything that had inspired foreign travellers and students proved to be negative for Estonian peasants, and the semantic field of Tartu acquired a new opposition between the townspeople and country people, peasants and merchants, familiar and alien all these being the features that spoil the previous Arcadian image and underline tensions. (Mihkelev 2002: 440-441) Similar oppositions concerning enlightenment transfer of German ideas existed also in Latvia according to Pauls Daija: "Thus the attitude towards peasants in Livonia and Courland - starting with the traditional stereotypes covering, for example, rudeness, laziness, superstition or alcoholism, and finally [...] gained ethnic connotations.” (Daija 2014: 361)

Juhan Liiv's poem Sa oled kui Iisrael vanast' (Like Ancient Israel, 1908) is one of the best examples of identifying Estonians with old nations:

\begin{abstract}
Thou, oh my fatherland, are like ancient Israel, the Israel of the prophets, you follow that ideal.

You stand beside the road that wanders to Moab, and from atop a mountain look out across Amon.

$[\ldots]$

You are tormented exactly like Israel.

May the creator of all protect you and guide.
\end{abstract}

(Liiv 2007: 87; trans. by Jüri Talvet and Harvey L. Hix)

The Bible functions as a metatext in Estonian culture, which describes Estonian culture itself via auto-communication. Another function of the Bible is to describe temporally and geographically distant cultures and countries which have influenced Estonian culture through cultural transformations. The appearance of an Estonian translation of the Bible (1739) was very significant in that Estonian culture became more dialogical, using both communication and auto-communication, and the relationships between the self and other were taken to a new level. 
MIHKELEV

The main themes of the Estonian contemporary writer Ene Mihkelson's (b. 1944) neo-mythological literary works (both poetry and prose) are the severance of the identity of Estonians after the war and attempts to rediscover the deeper continuity of identity, which are often partly condemned to fail, the intervention of social and political rules into personal self-knowledge, and the forced (and unconsciously accepted) forgetfulness of past relationships and of natural sources of self-creation. Mihkelson refers to several biblical legends in her poetry and novels, e.g. to the legends of John the Baptist, and Cain and Abel. She interweaves these different legends to describe national Estonian history and culture.

Mihkelson used the motif of Ahasuerus for the first time as a poetic subject in the collection Hüüdja hä̈l (A Calling Voice, 1993).

The legend of the Wandering Jew is connected with the biblical legend of the brothers Cain and Abel. Cain killed his brother Abel and his punishment was similar to the Wandering Jew's punishment, to travel as a refugee in the world, although Cain did it under the protection of God. The legend of Cain and Abel is reflected in civil wars in contemporary times, but Mihkelson presents the legends of the Wandering Jew and Cain and Abel in the context of Estonian history.

The legend of the Wandering Jew is meant to connect the dead and the living, as well as the real world and the world of the hereafter in Mihkelson's novel, but this does not work out, because the dead ancestors do not hear the voices of living people. The meeting with ancestors is just a dream (Mihkelson 2001: 490). Each name of one's predecessors is surrounded by mystical and mythical space. It is a space which includes events from the distant past. It is another world and we can only dimly imagine what happened so long ago. The same phenomenon also works if we read old myths, not only our own family myths, but myths which speak not only of personal identity but also of identity in a larger sense. These are the "stories about who and what we are and where we come from... Of greater importance than their truth value is the role they play in the formation of cultural identity. These myths are embodied by various cultural artefacts, literary texts included." (Lukas 2007: 75)

\section{Blaumanis, Vilde and our "own" decolonial modernism}

The Latvian writer Rūdolfs Blaumanis' (1863-1908) lyrical presentation of nature in his stories is connected with national culture, which is similar in Latvia, Lithuania and Estonia. It is mainly a peasant culture, where nature plays a major role in everyday life. The Estonian writer Eduard Vilde (1865-1933) was interested in different countries and cities, his first travels were mental travels 
through literature, and the German Theatre in Tallinn influenced the young Vilde very strongly. Perhaps the strong experiences of theatre were one of the reasons why Vilde's stories are so dramatic and intriguing. But it also means that the roots of Vilde's works are situated in romantic stories of adventures and noble heroes although Vilde was mainly a realist author. According to Richard Lehan "Realism was the bridge between the romance and the naturalistic novel" (Lehan 2005: 3). Lehan has studied the history of the novel, and he has the following opinion:

The novel had its origins in the middle class. The old romance was the narrative of the medieval aristocracy, celebrating the world of the manor and the heroics and love rituals of knightly class. The bourgeoisie wanted a fiction of its own, and the novel gave expression to the fate of the individual in a New World. [...] Before the realistic novel could take effect, however, it had to displace the romance. Cervantes did this in Spain, Defoe in England, Balzac in France, and Twain in America. (Lehan 2005: 34)

It can be said that Vilde did this in Estonia and Blaumanis in Latvia. But it can be said that all these European writers did not displaced romantic features definitely. Although Vilde's heroes usually originate from peasants these heroes are very similar to aristocrats, for example, Musta mantliga mees (The Man in the Black Cloak, 1886) etc. The noble and intelligent peasants were Vilde's heroes often, as well as the manor milieu.

The same we can say about Rūdolfs Blaumanis: the plots of his stories and plays often take us to the Latvian manors (for example, the play Uguni (In the Fire, 1905)). The lyrical descriptions of nature in Blaumanis' works also reflect Latvian folklore, the dainas. At the same time, these lyrical motifs make Blaumanis' style softer and emphasise romantic episodes which stand in contrast with the rational reality. Inguna Daukste-Silasproge has written that "in his depictions of country life and relationships, he also wove in the contemporary themes of power, money and property. Even so, Rūdolfs Blaumanis retained a style of prose from an earlier time - the dominant setting is the farm, with portrayals of specific characters [...]" (Daukste-Silasproge 2009: 18). The psychological element is particularly strong in Blaumanis' stories: he develops the characters and dramatic actions carefully, and he is "a master of psychology" (DauksteSilasproge 2009: 18).

Blaumanis wrote several short stories which have very exciting psychological plots, e.g. Raudupiete (Raudups' Widow, 1889), Nāves ènā (In the Shadow of Death 1900) and one of the most significant short stories in the context of critical realism, Andriksons (1898). The story depicts a conflict between a landlord 
MIHKELEV

and the peasant Andrikson, who rents his farm from the landlord. It is a very complicated $19^{\text {th }}$-century situation, reflecting both the historical and the colonial background. Andrikson comes to the manor to explain why he has cut down the oaks on his farm without asking the landlord's permission. The two men quarrel because neither of them understands the sense of justice of the other: the problem is that the landlord has his own rules, colonial rules, and the peasant has a different understanding of justice. Peasants also want to pass their property from father to son as landlords do. Andrikson leaves the manor, and in an act of revenge he sets fire to the forest. Then he realises that his children may be in the forest, and people tell him that his boys have not returned home. The fire is soon contained, and the landlord finds Andrikson's children and gives them to their father; he does not punish Andrikson, and Andrikson feels great remorse, which is his punishment.

This story is an exception in the context of realism at the end of the $19^{\text {th }}$ century. There are no noble heroes or noble peasants similar to aristocrats, as in Vilde's short stories and novels in his first period (e.g. Musta mantliga mees, 1886). There is no ideological opposition, i.e. bad landlord vs. noble peasant, which was a typical element of fiction at the end of the $19^{\text {th }}$ century and represented colonial or post-colonial relations. Blaumanis' story Andriksons also opposes the colonial patterns from the $18^{\text {th }}$ century enlightenment literature (see Daija 2014). This Blaumanis' story shows national and class oppositions being overcome, and merely presents human nature, both its bad and good sides. It seems Blaumanis was really an innovator in this way, and a de-colonial author who represented de-colonial freedom and independent thought in his works.

Blaumanis was also an innovative playwright. Benedikts Kalnačs has written on Blaumanis' plays:

In his plays Pazudušais dēls (The Prodigal Son, 1893) and Ugunī (In the Fire, 1905), we face a completely different level of awareness of changing times which becomes substantial for the characters of this drama. The concreteness of space (a minutely observed Latvian peasant's and German landlord's manor, respectively) and time (the events of the latter play are explicitly marked by the author as taking place 'before the uprising') provide principal coordinates among which the characters are placed. Blaumanis' plays which, on the one hand, are deeply rooted in the everyday experiences of the rural community, at the same time also manifest modernist literary qualities. (Kalnačs 2014: 35)

Blaumanis showed his interest in human nature in other short stories: Raudupiete (Raudups' Widow), Laimes klèpi (In the Lap of Happiness) and others. The roots of these stories lie in romantic tales, with their exciting adventures and 
passionate love stories. Although Blaumanis' stories were often set in manors (cf. Turgenev), they were targeted at more than the middle class, as pointed out by Richard Lehan, in his remarks about the middle class realist novel (Lehan 2005:3).

Nature expresses the feelings of human beings in Blaumanis's and Vilde's short stories; peasants live with nature, sometimes struggle against it and sometimes lose the struggle, e.g. in Blaumanis' Näves ènā (In the Shadow of Death). It seems the role of nature in Blaumanis' and Vilde's works represents the Baltic lifestyle, which affected peasants and aristocrats in different ways. Both writers used more of their "own" cultural system and language as metatext to describe the cultural system, rather than using external cultural systems and languages. They transformed realist, romanticist and psychological realist styles and languages into internal or "own" cultural system.

\title{
Conclusion
}

All of these stories and poems demonstrate how smaller and peripheral cultures find their own original national cultures and how cultural influences and transformations work through cultural dynamics processes. If we have our own Hamlet, Shakespeare, Dante and other cultural legends, we can communicate with other cultures, and they can communicate with us; we can describe our "own" culture via auto-communication.

\author{
Anneli Mihkelev \\ milennagm@gmail.com \\ Tallinna Ülikool \\ Eesti Keele ja Kultuuri Instituut \\ Slaavi Keelte ja Kultuuride Instituut \\ Narva mnt 25 \\ 10120 Tallinn \\ EESTI
}

\section{References}

Annist, A. 1993. Käsu Hans ja tema “ikulaul” Tartu hävitamisest a. 1704-1708. - Akadeemia, 1, 125-149.

Annus, E. 2012. The problem of Soviet Colonialism in the Baltics. - Journal of Baltic Studies, vol. 43, no. 1, 21-45.

Betts, R. F. 2004. Decolonization. Second Edition. New York and London: Routledge. 


\section{MIHKELEV}

Daija, P. 2014. Colonial Patterns in Latvian Popular Enlightenment Literature. Interlitteraria, 19/2, 356-371.

Daukste-Silasproge, I. 2009. Money or Love. Points of Connection in the Short Stories of Eduard Vilde and Rūdolfs Blaumanis. - A. Mihkelev, ed., Turns in the Centuries, Turns in Literature. Comparative Approach to Estonian and Latvian Literatures in A European Context. Tallinn: The Under and Tuglas Literature Centre of the Estonian Academy of Sciences, 17-31.

Epner, L. 1998. Kahe „Libahundi” vahel ehk Antigone ja Hamlet. - M. Laak, ed., Traditsioon ja pluralism. Tallinn: Tuum, 169-184.

Kalnačs, B. 2014. 20 ${ }^{\text {th }}$-Century Baltic Drama: Comparative Paradigms. - Interlitteraria, 19/1, 33-53.

Kruuspere, P. 2006. Is It Ghosting? The Motifs and Allusions of Hamlet in Estonian Drama. - C. Hasselblatt, ed., Different Inputs - Some Output? Autonomy and Dependence of the Arts Under Different Social-Economic Conditions: The Estonian Example. Maastricht: Shaker Publishing BV, 35-47.

Lehan, R. 2005. Realism and Naturalism. The Novel in an Age of Tradition. Madison, Wisconsin: The University of Wisconsin Press.

Liiv, J. 2007. Meel paremat ei kannata. Valik luulet eesti ja inglise keeles. The Mind Would Bear No Better. A Selection of Poetry in Estonian and English. Ed. by J. Talvet. Tartu: Tartu Ülikooli Kirjastus.

Lotman, J. 2009. Culture and Explosion. Berlin, New York: Mouton de Gruyter.

Lukas, L. 2007. The Baltic-German Settlement Myths and Their Literary Developments. - A. Mihkelev, B. Kalnačs, eds., We have Something in Common: The Baltic Memory. Tallinn: Eesti TA Underi jaTuglase Kirjanduskeskus, 75-85.

Mihkelev, A. 2002. Texts of Tallinn and Tartu in Estonian Poetry. - V. Sarapik, K. Tüür, M. Laanemets, eds., Koht ja paik. Place and Location II. Tallinn: Eesti Kunstiakadeemia; Underi ja Tuglase Kirjanduskeskus, 431-454.

Mihkelev, A. 2013. The Dialogue with Hamlet: Paul-Eerik Rummo's "Hamlet's Songs" as an Example of the Existential Paradigm in Estonian Culture. - Interlitteraria, $18 / 1,258-272$.

Mihkelson, E. 2001. Ahasveeruse uni. Tallinn: Tuum.

Mignolo, W. D. 2011. The Darker Side of Western Modernity. Global Futures, Decolonial Options. Durham \& London: Duke University Press.

Olesk, S. 2001. Paul-Eerik Rummo. - E. Annus, L. Epner, A. Järv, A, S. Olesk, E. Süvalep, M. Velsker, Eesti kirjanduslugu. Tallinn: Koolibri, 443-446.

Oras, A. 2003. Luulekool I. Tartu: Ilmamaa.

Rummo, P.-E. 2006. Hamlet's Songs. Trans. by J. Talvet, H. L. Hix. - H. L. Hix, ed., On the Way Home. An Anthology of Contemporary Estonian Poetry. New Delhi: Sarup \& Sons, $8-10$.

Salumets, T. 2006. Conflicted Consciousness: Jaan Kaplinski and the Legacy of Intra-European Postcolonialism in Estonia. - V. Kelertas, ed., Baltic Postcolonialism. Amsterdam/New York: Rodopi, 429-450. 
Modernity, Intertextuality and Decolonization

Sommer, L. 2001. Paul-Eerik Rummo. - D. Kareva, ed., Tuulelaeval valgusest on aerud. Valik eesti moodsat luulet. $=$ Windship with Oars of Light. Estonian Modern Poetry. Tallinn: Huma, 131.

Unt, M. 2006. Poet and Politican Paul-Eerik Rummo. - Estonian Literary Magazine, 22, 4-7.

Veidemann, R. 2000. Eksistentsialistliku paradigma avaldusi 1950.-60. aastate eesti kirjanduses. - L. Epner, P. Lilja, eds., Taasleitud aeg. Eesti ja soome kirjanduse muutumine 1950.-1960. aastatel. Kadonneen ajan arvoitus. Viron ja Suomen kirjallisuuden muuttuminen 1950.- ja 1960-luvulla. Tartu Ülikooli eesti kirjanduse õppetooli toimetised 2. Tartu: Tartu Ülikool, 41-50. 